\title{
REVISION OF THE THANEROCLERINAE (Cleridae, CoL.)
}

\author{
BY \\ J. B. CORPORAAL \\ Amsterdam \\ With three plates \\ (I6th. Communication on Cleridae)
}

Mr. E. A. Chapin (in "Classification of the Philippine Components of the Coleopterous family Cleridae"; Philipp. Jrn. Sc. Vol. 25, No. 2, 1924, p. 16525I) was the first to recognize the Thaneroclerinae as a distinct subfamily of the Cleridae, characterized chiefly by the broadly dilated anterior tarsi and the almost entire eyes. The discovery of a new species from Kashmir and of one from Sumatra has gradually led me to make a complete revision of this interesting group, in which I was very materially assisted by my friend Mr. P. VAN DER WIEL, who also executed all the figures, which accompany this paper, with one exception ${ }^{1}$ ).

Further this work was supported very largely by the help of almost all important scientific institutions and that of some private collectors; most of these have entrusted to me all the materials which they possessed of this group. Therefore my grateful acknowledgments are due to: British Museum, London; Deutsches Entomologisches Institut der Kaiser Wilhelm-Gesellschaft, BerlinDahlem; Mr. F. C. Drescher, Bandoeng, Java; Mr. H. Kôno, Sapporo, Jápan; Dr. D. Mac Gillavry, Bergen-Binnen (Netherl.); Museo Civico di Storia Naturale, Genova; Muséum national d'Histoire Naturelle, Paris; Museum nationale hungaricum, Budapest; Naturhistorisches Museum, Basel; Naturhistorisches Museum, Hamburg; Naturhistorisches Museum, Wien; Naturkundemuseum der Stadt Stettin; Mr. R. OвERThür, Rennes; Mr. Maurice PIc, Digoin; Rijksmuseum van Natuurlijke Historie, Leiden; Staatliche Museen für Tierkunde und Völkerkunde, Dresden; University Museum, Oxford; U.S. National Museum, Washington; Dr. D. L. Uytren boogaArt, Heemstede; Zoologisches Institut der Universität in München; Zoologisches Museum der Universität, Berlin.

My special thanks are due to Mr. K. G. Blair, of the British Museum, and

I) With a few species, which had erroneously been placed in this group, I have dealt in a previous paper (Deux nouveaux genres de Clérides et remarques sur un autre genre; 13me Communication sur les Clérides; in Rev. franç. d'Entom. III, 1936, p. 205-21 I). 
to Mr. P. Lesne, of the Museum in Paris, who, according to the rules of their museums, could not send me unique specimens or types, but with whom I have circumstantially corresponded; they have examined all characters on which closer information was needed, and have executed several comparisons with those types.

The genera of the Thaneroclerinae can be distinguished as follows:

I. Antennal club consisting of two joints ${ }^{1}$ ) . . . . . Neoclerus Lewis Antennal club consisting of three joints . . . . . . . . . . . . 2

2. Anterior coxal cavities open behind; flanks of prothorax non-carinate. . . . . . . . . . . . . . . . . . . . . Zenodosus Wolc. Anterior coxal cavities closed behind; flanks of prothorax more or less carinate . . . . . . . . . . . . . . . . . . . . . . . 3

3. Elytra with even and regular rows of elongate punctures and markings of silvery hairs; carination of prothorax obsolete . . Cyrtinoclerus Chpn. Punctuation of elytra irregular, or, if regular, not in rows; pubescence yellow or brown; carination of prothorax distinct . . . . . . . . 4

4. Prothorax constricted behind . . . . . . . . . . . . . . 5 Prothorax rounded behind . . . . . . . . . . . . . . 6

5. Elytra in the middle with a depression along the suture. Thaneroclerus Lef. Elytra evenly rounded, ornate with tufts of hairs Allothaneroclerus gen. nov.

6. Elytra with very distinct depressions. . . . . Parathaneroclerus Pic Elytra not or hardly depressed . . . . . . . . . . . . . . . 7

7. Head behind the eyes hardly narrowed, legs relatively short and stout . . . . . . . . . . . . . . . . . . . . . . Ababa Casey Head behind the eyes distinctly rounded and narrowed; legs longer and more slender. . . . . . . . . . . . . . . . . 8

8. Body short and stout . . . . . . . . . . . . Isoclerus Lewis Body elongate, slender . . . . . . . . . . Lyctosoma Lewis

\section{Genus THANEROCLERUS Lefebvre}

Thaneroclerus Lefebvre, Bull. Soc. Ent. Fr. VII, I838, p. I3.

$=$ Thaneclerus ChenU, Encycl. d'Hist. Natur. Col. II, I860, p. 247.

$=$ Thanateroclerus Gemm. et Harold, Cat. Col. VI, I869, p. 1739.

I. Pubescence of elytra and body consists of fine, curved and rather adpressed hairs, which are directed forward. Depressions on elytra very shallow . . . . . . . . . . . . Th. quasitardatus nov. sp. Pubescence consists of long, erect, straight hairs .

I) This character is due to the circumstance, that the last two joints are grown together; the seam is still faintly discernible. 
2. Elytra somewhat broadened towards apex; at about half their length, along the suture, with rather short, deep depressions; two more depressions at the base near the suture and next to the humeral angles, which latter hence are distinctly marked. Central depression on prothorax very strong .

Th. impressus Pic

Elytra nearly parallel; the depressions along the suture longer but shallower and less distinctly marked; no separate depressions at base nor next to the humeral angles, which latter therefore do not appear so prominent. Central depression on prothorax weaker . . . . . . . . . . . . . . 3

3. Robust species; central impression on prothorax short and deep; elytra relatively long and convex, with feeble impressions along the suture . . . . . . . . . . . . . . . . . . . . . . . . Th. aino Lewis Smaller species; elytra relatively shorter : . . . . . . . . . . . 4

4. Central depression on prothorax narrow, long and deep, reaching almost down to the base. Elytra rather short, in basal third with a distinct but short depression; close to it the suture is a little raised; near the scutellum the elytra are altogether even; the suture is not raised there .

Th. termitincola nov. sp. Central depression on prothorax short and broad, shallow, in some examples somewhat indicated in basal part. Elytra a little longer, with a depression along the suture from near the base till well over the middle; suture in this region distinctly raised. . . . . . . . . . . Th. Buquet Lef.

1. Thaneroclerus Buquet Lefebvre, Ann. Soc. Ent. Fr. IV, I835, p. 577, t. I6, f. 4 .

$=$ Th. Buqueti Westw., Bull. Soc. Ent. Fr. VII, I838, p. 13, et auct. div.

$=$ Th. Girodi Chevr., Bull. Soc. Ent. Fr. (5) X, I880, p. 3 I.

= (Metademius) tabacci Matsumura, Dainippon Gaichuzensho II (? I935), p. 234.

The synonymy of Th. Girodi Chevr. has been confirmed by Mr. P. Lesne, who had the kindness to compare the unique typical specimen in the Paris museum to numerous samples from several localities; also I have, by Prof. G. D. Hale Carpenter's kindness, been able to examine a second specimen in the University Museum in Oxford, bearing a label with a letter $W$ in a diamond-shaped frame (which means that it originated from J. O. WestwooD's collection). It was accompanied by a very old label: “Clerus Buquet Lefebvre in Ann. Soc. Ent. France V. . . . P1. . . . . with its larva, Pupa \& Cocoon. Presented by M. A. Lefebvre July I837." This specimen also agrees fully with specimens of $T h$. Buquet from Java and of "Th. Girodi" from the West Indies. In Mr. R. OвеRтнüR's collection is one specimen marked “type", from Mr. James Thомson's collection, labelled "Thaneroclerus Buquetii Lef. West. An. S. ent. I 838 t. 7. p. XIII du Bullet. Bengale". The figure which accompanies LEFEBVRE's original description is in so far somewhat misleading, 
that it shows no trace of depressions on the elytra, whereas both the above named original specimens, as well as the third in the Paris museum, examined for me by Mr. P. LesNe, distinctly, through rather faintly, show them. The distinctness and depth of these depressions are somewhat variable. Another specimen in Mr. R. Oberthür's collection bears a label "ex Musaeo E. Steinheil-Cuba", and one "Taneroclerus Girodi Chevll. Bull. Ann. Soc. Ent. France I880. p. XXXI". This specimen unquestionably belongs to this species. I further have received a cotype of Mr. Matsumura's Metademius tabacci, which also belongs to this species.

Th. Buquet is a very widely spread species. I saw specimens from North America: Tampa Fla.), Quincey (Fla.), New York, California; West Indies : Cuba (Santo Domingo, La Habana), Porto Rico, Key West; South America: Medellin (Columbia), "Brésil", Bahia; Africa: Berbera (Somali), Port Louis (Mauritius); Netherlands: Amsterdam, Leiden, The Hague, Rotterdam; Germany: Liegnitz, Schweidnitz; Switzerland; China: Woochow (prov. Kwangsi); Japan; British India: "Indes", Bombay, Maïssour, Manganali ; Ceylon: "Ceylon", Hambantote; Birma: "Birma”, Mandalay, Moulmain, Palon (Pegu), Rangoon; Tonkin: Env. de Hoa-Binh; Sumatra: "Sumatra", Soengei Krapoh, Padang; Java: "Java", Samarang, Tjilatjap, Batoerraden, DagoBandoeng, Tjibintaro, Buitenzorg, Preanger 4-6000', Wringin; Island Madura ; Sambawa ; Celebes : "Celebes", Tombugu ; Philippine Islands: "Philippines”, Luzon, Manila, Irisan, Benguet, Los Baños; Oceania: Honolulu.

This species is a predator on several insects living in groceries, spices, drugs and tobacco. It was found very often in coffee, infested with Araecerus fasciculatus DE G., further in tobacco and in drugs and spices, infested with $A$. fasciculatus and Lasioderma serricorne $F$, in rice with Tribolium ferrugineum $F$. and Calandra oryzae L., and (in California) in tea from China.

Length $4,7-6,3 \mathrm{~mm}$ - Plate I, fig. I.

The ab. pondicherryanus SPIN. was described on dark, piceous specimens. 1 saw such very dark specimens from Ceylon; British Indies: "Indien", Indes or., Kodeicanel; Tonkin: Huong By; Java: Samarang.

Th. dermestoides KLug, of which Prof. Kuntzen in Berlin had the kindness to entrust me with the type specimen, is no more than a variety; it is smaller $(3,7-4,1 \mathrm{~mm})$ and narrower; the punctuation of the elytra is, relatively to the size, a little coarser. I saw specimens from Arabia felix (the type), further from New York; Jamaica; Amsterdam; Pondicherry; Burma; Annam: Tanh-hoa; Sumatra: Boenga Mas (Palembang); Java : Preanger 4-6000'. Plate I, fig. 2.

2. Thaneroclerus aino Lewis, Ann. Mag. Nat. Hist. (6) X, I892, p. I9I.

I saw one specimen from Japan (Junsai, near Hakodate). One more specimen is in the British Museum.

Length $6,9 \mathrm{~mm}$ - Plate I, fig. 3 . 
3. Thaneroclerus impressus PIC, L'Echange XLII, I926, No. 423, hors-texte p. 22.

I saw three specimens, all from Tonkin.

Length $7,5-8,0 \mathrm{~mm}$ - Plate I, fig. 4 .

\section{Thaneroclerus quas it a $\mathbf{r} \mathbf{d}$ a t $\mathbf{u} s$ nov. sp.}

Th. concoloriter testaceus aut brunneus, Th. Buquet affinis et similis, sed elongatior, depressionibus in prothorace et elytris minus distinctis et profundis, pilis vestitus; his pilis sat longis, pronis, in sutura et margine elytrorum pilis brevioribus, adpressis, resupinis intermixtis.

Length $5,6-5,8 \mathrm{~mm}$ - Plate I, fig. 5 .

Yellowish brown to brown; head and prothorax a little darker, legs and antennae of the same colour; in the darker specimens the apical joints of the antennae are of a somewhat lighter colour. General form a little more elongate than in Th. Buquet; elytra more convex, on the sides a little more rounded; depressions along the suture nearly obliterated, so that the suture is hardly elevated. Fore part of prothorax (as far as the narrowed portion) a little broader than long; the narrowed part short; central impression on the prothorax narrower and deeper than in $T h$. Buquet, vanishing in the hind portion. Head between the eyes less convex than in Th. Buquet; front margin of clypeus feebly emarginate, eyes less convex than in Th. Buquet. $\mathrm{Punctuation}$ on the elytra rather coarse and dense, fairly regular, not in rows; only along the suture a rather regular row of deeper points. The points are hardly elongate; sides of elytra coarsely (towards apex somewhat finer) and regularly punctate. Punctuation on prothorax finer than on the elytra, regular; points a little larger than the interstices. $\mathrm{H}$ a irs light yellowish, on the elytra rather long, strongly curved, directed forward; on the suture a row of shorter, straight hairs, directed backward; on the sides a row of fine, curved, rather adpressed hairs, directed backward. Hairs on prothorax curved, rather adpressed, directed forward; head with shorter, straight hairs, directed forward; sides of head and prothorax without erect, straight, long hairs.

I have chosen the name of quasitardatus, as I must suppose that the forward direction of the hairs must cause some hindrance when crawling through narrow passages.

Five specimens, received for identification from the Forest Research Institute, Dehra Dun (India), labelled: ex Pinus excelsa, Dorus 6000, Kolab valley, Kashmir, 18. V. 1928, C. F. C. Beeson; ex Ulmus wallichiana, U. Munda 7200', Pirpinjal, Kashmir, ıo. V. 1928, C. F. C. Beeson; ex Quercus incana (dead), Bajwar, Almors, U. P., I4. VI. 1937, J. C. M. Gardner.

\section{Thaneroclerus te $\mathbf{r} \mathbf{m i}$ incola nov. sp.}

Th. obscure brunneus. Habitus qualis in Th. Buquet; sutura elytrorum in medio tantum subelevata, prope basin plana; elytra in medio subdepressa; haec 
depressio minus extensa et minus profunda quam in Th. Buquet. Prothorax valde, subparalleliter sulcatus.

Length $4,0-4,8 \mathrm{~mm}$ - Plate I, fig. 6.

Dark brown to piceous, with the suture, shoulders and margins of the elytra reddish brown; head and prothorax a little lighter; legs lighter or darker reddish brown; antennae a little darker than the legs; their apices somewhat lighter in colour. General form as in Th. Buquet; elytra in basal third with a slight depression, which makes the suture appear a little raised; near the scutellum the elytra are altogether even, also in the apical half. Fore part of prothorax (as far as the narrowed portion) much broader than long; narrowed portion longer than in Th. Buquet and in Th. quasitardatus; central impression narrow and rather deep, distinctly continued in the narrowed portion. Head between the eyes less convex than in Th. Buquet; front margin of clypeus feebly emarginate (as in Th. quasitardatus); eyes proportionally smaller than in both the compared species, more convex than in Th. Buquet. P u n c t ua tion as in Th. Buquet, but a little less coarse and tending to forming rows; along the suture no row of coarser punctures as in Th. quasitardatus. Punctuation on the prothorax as in Th. Buquet, finer than on the elytra, rather regular; punctures round, interstices a little larger than the punctures. Punctuation on the head a little finer than on the prothorax, but sparser, interstices much larger than the punctures, towards the front margin of the clypeus confluent, forming fine longitudinal wrinkles. $\mathrm{H}$ a i r s light brown to brown, on head, prothorax and elytra disposed as in Th. Buquet.

A small series of this interesting species was found by Dr. Edw. JACOBson at Haraukloof, Sumatra's West Coast, in the nests of the termite Hospitalitermes medioflavus HoLMGR., which were adherent to perpendicular walls of rock. The hard substance of these nest was devoured, and sieved, by the burrowing of the beetle Ptinus rugosithorax PIc, and the latter were hunted by the Thaneroclerus.

\section{Genus LYCTOSOMA Lewis}

Lyctosoma Lewis, Ann. Mag. Nat. Hist. (6) X, I892, p. I92.

The palpi in this genus are not fusiform, at least not both; SchenkLing, who had not seen a specimen, was however quite right (in Wr'rsman, Genera Insect. I3, Cleridae, I903, p. 30 \& 54) in thus reading the description by LEwIs, which simply says "palpi fusiform", but Mr. BLAIR, who, on my request, had the kindness to examine the unique type specimen in the British Museum, informs me that only the last joint of the maxillary palpi is fusiform, or tapering rather than cylindrical; the labial palpi have a large, securiform terminal joint.

I. Body of a uniform, yellowish brown . . . . . . L. parallelum Lewis Body of a brownish red, with on the elytra a black, transverse median fáscia . . . . . . . . . . . . . L. elongatum Schenkl. 
1. Lyctosoma parallelum Lewis, Ann. Mag. Nat. Hist. (6) X, I892, p. 192. $=$ L. (Thaneroclerus) par'um (pars) SchenkL., Ent. Mitt. V, 19r6, p. 222. I have seen specimens from the following localities: China: Suifu (Szechuan); Sumatra: "Sumatra" (partly from tobacco bales), Indrapoera (Sum. centr.), Fort de Kock; Java: Gunung Gedeh, Tjigembong, BandoengTjiboerial, Bandoeng-Tjipaheut, Soember Asin, Batoerraden.

This species, though rare, appears therefore to have a rather wide distribution. Mr. BlaIR, who compared a number of these to the type specimen, stated in his letter to me, that the difference between Schenkling's type and "Cotype" of Thaneroclerus parvus and the type specimen of LEwis' Lyctosoma parallelum is much less than between two individuals of that series, and that he could find no definite character to separate them from the type specimen (from Nagasaki, Japan, under bark), saying at the same time that the wide difference in localities should make them almost certainly specifically distinct. I think, however, that the localities given above are geographically sufficiently continuous to justify my regarding all those individuals as belonging to one species.

Length $2,6-4,0 \mathrm{~mm}$ - Plate I, fig. 7 .

var. parvulum nov. var. The two individuals on which Schenkling described his $T h$. parvus are not exactly alike: the specimen from Tjigembong (Java, Priangan, taken by myself II. I9I 5 ; in the Berlin-Dahlem museum, and to which he had attached a label "type") is in all particulars like the others of the above-named series and like Lewis' type-specimen: the impressions on the prothorax are very shallow and weakly indicated. The second one (also taken by myself at Dinewatie, quite near Tjigembong VIII. 19I5) differs in having quite distinct impressions on the prothorax (see fig. 8). I propose for this variety the name of parvulum (= parvus ScHenkl. pars) and design as its typc the unique Dinewatie specimen (in the Amsterdam museum).

Length $3,4 \mathrm{~mm}$ - Plate I, fig. 8 .

2. Lyctosoma (Thaneroclerus) elongatum SchenkL., Deutsche Ent. Zts. 1906, p. 278 .

I have only seen the two individuals described by Schenkling, from Yunnan (DONCKIER). One of these specimens has been graciously given in exchange by Dr. W. Horn to this museum.

Length 2,9 $\mathrm{mm}$ - Plate I, fig. 9 .

\section{Genus PARATHANEROCLERUS Pic}

Parathaneroclerus PIC, L'Echange LI, I936, p. 20.

1. Parathaneroclerus triimpressus PIC, L'Echange LI, I936, p. 20.

$\mathrm{Mr}$. PIc had the kindness to entrust me with one cotype, from Nova Teutonia, Brasil, which afterwards he gave in exchange to this museum.

Length 2,6 mm - Plate I, fig. Io. 


\section{Genus ALLOTHANEROCLERUS nov. gen.}

Generi Thaneroclero valde affinis et similis, sed elytris non impressis, pilis fasciculatis ornatis.

This genus, which I erect for Neoclerus tuberculatus SCHENkL., is closely related to Thaneroclerus, as well as Isoclerus, Lyctosoma and Parathaneroclerus. It is distinguished by the elytra, which show no depressions, and bear tufts of hairs.

1. Allothaneroclerus (Neoclerus) tuberculatus SchenkL., Deutsche Ent. Ztschr. I906, p. 278.

I saw four specimens of this species, all from Ceylon (leg. Nietner; Lewis).

Length $3, \mathrm{I}-4,6 \mathrm{~mm}-$ Plate II, fig. I I.

\section{Genus ISOCLERUS Lewis}

Isoclerus L.ewis, Ann. Mag. Nat. Hist. (6) X, I892, p. I9I.

I. Small, prothorax black, nearly parallel, legs black with yellow tarsi. . . . . . . . . . . . . . . . . . . . . I. sarazuacensis nov. sp.

Larger, prothorax red, narrowed towards the base, legs reddish $I$. pictus Lewis

1. Isoclerus pictus Lewis, Ann. Mag. Nat. Hist. (6) X, 1892, p. I9I.

This species is somewhat variable. The outline of the prothorax varies a little (see figs.); the three impressions on its disc can be more or less confluent; the elytral markings also are variable. In the type-specimen in the British Museum (fig. I2) the subapical transverse fascia is uninterrupted; the subbasal fascia is interupted at the suture. The figure was sketched after the cotype, and corrected according to remarks of Mr. Blair, who had the kindness to compare this sketch with the type. In a specimen from Chuzenji, Japan, received from Dr. H. Kôno (fig. I3), now in the Amsterdam museum, both fasciae are uninterrupted, and the suture between the subbasal and the submedian fasciae is very narrowly reddish yellow. In a "cotype" in the British Museum (fig. 14) both fasciae are interrupted at the suture; in this specimen also the small black spot behind the shoulder, in the subbasal fascia, is missing.

L o c a lities: Nikko, Japan, 3.6-21.6.188o (Lewis leg.) and Chuzenji, Japan, 12.8.191 5 (received from Dr. H. KôNo).

Length $3,2-3,7 \mathrm{~mm}$ - Plate II, figs. 12-14.

2. Isoclerus s a ra wa censis nov. sp.

I. minutus, piceus, marginibus prothoracis elytrorumque subparallelis, in utroque elytro maculis duabus flavis subluniformibus. Pedes picei, tarsi rufoflavi. Antennae piceae, articulis duobus primis rufo-flavi.

Much smaller than $I$. pictus, general form more elongate, pubescence erect. Prothorax narrower than the elytra, a little longer than broad, sides nearl; 
parallel; on the disc three shallow impressions. Elytra rather parallel, piceous, with two lunate, bright yellow spots on each. I.egs robust, as in I. pictus, dark brown, with reddish-yellow tarsi. Antennae brown; the two basal joints reddish yellow.

Length 2,I $\mathrm{mm}$ - Plate II, fig. I5.

Only one specimen in the British Museum, labelled: No. L 625, Mt. Matang, W.-Sarawak, 3000', G. E. BRYANT, 20. XII. I9I3.

\section{Genus NEOCLERUS Lewis}

Neoclerus Lewis, Ann. Mag. Nat. Hist. (6) X, I892, p. I90.

I. Prothorax towards the base slightly narrowed, with distinct, though obtuse basal angles, with hardly any impressions . . . . N. nanus Schenkl. Prothorax towards base more strongly narrowed, basal angles rounded. . 2

2. On the prothorax a central impression is faintly indicated; no lateral impressions. Black central and apical fasciae on the elytra not interrupted at the suture . . . . . . . . . . . . . . N. nilgiriensis nov. sp. On the prothorax the central and lateral impressions are distinct. Median fascia dissolved into two rounded spots ... . . . . N. ornatulus-group

1. Neoclerus nanus Schenkl., Ann. Soc. Ent. Belg. LXV, I901, p. Io6.

Now that I have the opportunity to compare cotypes of ScHenkLing with all the other species, I should like to complete his description (he could not compare his species with its closest relatives) as follows:

General form rather slender. Pubescence rather long, erect. Prothorax rounded at the sides, narrowed towards the base, with distinct hind angles, at the sides a little less rounded than the other species of the genus, no central impression, lateral impressions no more than weakly indicated. E 1 y $\mathrm{ra}$ a little more parallel than in the other species. Le g s of normal build. Colour: Head and prothorax of a lighter or darker reddish brown Elytra red, with a black median fascia, which can be interrupted at the suture, a more or less distinct, triangular spot round the scutellum, and a more or less distinct, interrupted, transverse fascia before the apex.

Schenkling's figure (in Wytsman's Genera Insectorum: Cleridae, 1903, Pl. 3, fig. II) represents an extreme form, with a distinctly interrupted median fascia and both the other black markings missing; I think, that in the figured specimen there may have been faint traces of these, which the delineator possibly has overlooked.

Length $2,6-4,0 \mathrm{~mm}$ - Plate II, figs. 16-i 7 .

Described from Sumatra (Painan, Ins. Bodjo). I further saw specimens from Malacca (Penang), Borneo (W.-Sarawak: Quop) and from "Java”. Moreover there is in this Museum a fine series, collected by my friend F. C. Drescher in Java: Gunung Tangkoeban (Priangan) in the months of March, June, Octo- 
ber and November. Mr. Drescher's specimens were for the greater part bred from a hard, woody tree-fungus (Fomes melanoporus Mont.). This fungus was further inhabited by three species of Tenebrionidae: Bolitonaeus vacca Мотsch., Labidocers Drescheri PIC and Platydema perpolitus GEB., and by a Cisid: Xylographus javanus PIC. Probably these beetles and their larvae were hunted by the Neoclerus.

\section{Neoclerus nilgiriensis nov. sp.}

N. quinquemaculato affinis et similis, sed marginibus magis parallelis, prothorax versus apicem paulo, versus basim valde angustatus; in prothorace impressiones laterales obliteratae, impressio centralis leviter indicata.

General form rather slender. Pubescence rather long, erect. Prothorax a little narrower than the elytra, strongly constricted behind, very little attenuated in front, with a weakly indicated central impression and without lateral impressions. E 1 y $\mathrm{t}$ a narrower, more parallel than in the other species. Legs as in $N$. quinquemaculatus. Colou r: Head reddish brown, darkened towards the base; prothorax dark brown, in front a little lighter; elytra dark red, with black transverse fasciae running across the suture, which also is altogether black.

Length $4,0 \mathrm{~mm}$ - Plate II, fig. 18.

Only specimen in the British Museum, labelled: H. L. Andrewes, Nilgiri Hills.

\section{ornatulus-group}

The three species of this group, to which $N$. nilgiriensis can be added, are closely related to eachother. It is difficult to expose the differences in a synoptic table; therefore I prefer the following way:

\section{Neoclerus ornatulus} Lewis.

N. ornatulus Lewis, Ann. Mag. Nat. Hist. (6) X, I892, p. I9O.

Length $3,0-5,0 \mathrm{~mm}$.

General form more robust than in both the other species.

$\mathrm{Pubescence}$ of prothorax and elytra moderately long and less directed forward than in 5-maculatus.
4. Neoclerus 5-maculatus Gorh.

N. (Thaneroclerus)

quinquemaculatus Gorh., Ann. Mus. Genova (2) XII, I892, p. 738 .

$3,4 \mathrm{~mm}$.

slenderer than in both the other species.

very long and rather strongly directed forward.
5. Neoclerus notatus Pic $N$. notatus Pic, Mél. exot.-ent., LVI, I930, p. I3.

$4,4 \mathrm{~mm}$.

robuster than in 5-maculatus. but slenderer than in ornatulus. rather long and erect, hardly directed forward. 
Prothorax narrower than the elytra, as long as broad, on the sides less attenuated than in 5-maculatus, also towards the base less constricted.

I m pressions on prothorax: central and lateral impressions much stronger than in 5-maculatus, also towards the base less constricted.

E 1 y $t r$ a relatively broader than in both the other species; pubescence on the sides is less long and erect than in 5-maculatus.

L e g s strongly built, robuster than in both the other species.

Colou r: Head and prothorax of a light reddish brown, prothorax with two ill-defined dark longitudinal strokes, which do not reach the front margin; often the prothorax is entirely dark, excepting the front margin. Elytra red (darker than in 5-maculatus), black spots broader than in both the other species; those near the scutellum of both elytra nearly confluent. Legs as in 5-maculatus.

F i g u r e: Plate II, fig. Plate II, fig. 20. Ig. much narrower than the elytra, about as long as broad, on the sides rounded to the apex, towards base very strongly attenuated and constricted.

all impressions only weakly indicated.

relatively narrower than in both the other species; pubescence on the sides very long and erect.

of normal build, slenderer than in both the other species.

Head and prothorax entirely of a light, reddish brown. Elytra of a clear red; black spots smaller than in both the other species, notably the subapical ones; legs and antennae of a yellowish brown, the tibiae at the base a little darker. narrower than the elytra, broader than long, on the sides less rounded and in front and at base less attenuated than in 5-maculatus.

central impression more distinct than in 5-maculatus, broader but shallower than in ornatulus.

relatively broader than in 5-maculatus, narrower than in ornatulus; pubescence on the sides less long and erect than in 5maculatus.

intermediate between ornatulus and 5-maculatus.

Head and prothorax altogether of a dark reddish brown, on the prothorax two ill-defined darker longitudinal strokes. Elytra of a darker red than in 5-maculatus, black markings larger than in 5-maculatus. Legs as in 5-maculatus.

Plate II, fig. 2I. 
L o c a 1 i t y: Japan: Burma. Tonkin: Hoa-Binh.

Kiushiu, Oyayanca, Ikenchaiya, Nikko, Higo. Formosa : Taihorinsho, Fuhosho.

\section{Genus ZENODOSUS Wolcott}

Zenodosus Wolcott, Ent. News XXI, I9Io, p. 32 r.

$=$ Xenodosus Champlain, Proc. U. S. Nat. Mus. LVII, I920, p. 636.

1. Zenodosus (Clerus) sanguineus SAY, Boston Journ. Nat. Hist. I, I835, p. I62. A not uncommon species, which has a wide distribution in Canada and the U. S. A.

Length $4, \mathrm{I}-5,7 \mathrm{~mm}$ - Plate II, fig. 22.

\section{Genus ABABA Casey}

Ababa Casey, Ann. N. Y. Ac. Sci. IX, I897, p. 653.

= Prionodera Wolcotr, Publ. Field Mus. Chicago VII, I9Io, p. 396.

= Prionostichaeus WolcotT, Ent. News XXII, I9I I, p. I25.

$=$ Wolcottella R. LucAs, Cat. alph. I920, p. 669.

1. Ababa (Clerus) tantilla J. LEC., New spec. Col. 1865, p. 96.

=A. crinita CASEY, Ann. N. Y. Ac. Sci. IX, I897, p. 653.

This species, though very sparsely represented in the collections of the world, has a wide distribution in the middle and Southern parts of the U.S.A., from where I have seen 4 specimens (Texas, Missouri and Alabama). Further I saw specimens from Mexico and from Bahia (Bras.), both found by Grouvelle in tobacco bales, and one from Zamboanga (Mindanao, Philippine Islands) in the BAKER collection in Washington, which I cannot but regard as belonging to the same species. The small differences shown by the specimens from Mexico, Bahia and the Philippine Islands do not go beyond the range of variation of the U.S.A. specimens. The small size and the unpretentious, uniformly piceous colour are perhaps the cause that it has often escaped notice. Nor does the general form suggest at once its subordination to the Cleridae (CASEY, e. g., ranged the genus Araba originally under the Othniidae). Possibly, when collectors in the tropics give more attention to the minute forms, the species may prove to be nearly a cosmopolite.

Some examples in the Washington Museum were reared from an old specimen of Polypolyporus ignarius (a woody tree-fungus).

Length $1,8-2,6 \mathrm{~mm}$ - Plate II, fig. 23 (the figured specimen is from Mexico). 


\section{Genus CYRTINOCLERUS Chapin}

Cyrtinoclerus Chapin, Phil. Jrn. Sc. XXV, No. 2, 1924, p. 253.

1. Cyrtinoclerus cyrtinoides Chapin, Phil. Jrn. Sc. XXV, No. 2, 1924, p. 254 , pl. I, fig. 6.

As the unique type specimen of this species, in the Washington Museum, could not be sent abroad, I know it only from Mr. Chapin's very elaborate description, and from a very beautiful drawing; executed by Mrs. A. M. AwL in Washington, which, with Mr. Chapin's kind permission, I reproduce on Plate III. In the type specimen (U.S.N.M. Cat. No. 40605) both hind legs are missing.

Length $3 \mathrm{~mm}$ - Plate III, fig. 26.

L o c a lity: Basilan, Philipp. Isl. (collected by C. F. BAKer).

\section{Cyrtinoclerus indicus nov. sp.}

C. lateribus parallelis, elongatus, rufo-brunneus, punctis elytrorum ad margines in ordines positis, ad discum versus subtilioribus et sparsioribus. In utroque clytro penicillis quatuor, quorum uno nigro, tribus argenteis. Pedes graciliores quam in specie, quae vocatur C. cyrtinoides; tibiis subcurvatis. Subtus rufoflavus; sternitum primum aeque longum ac tria sternita proxima.

Length $3,8 \mathrm{~mm}$ - Plate II, figs. 24-25.

Ge neral for more parallel than in $C$. cyrtinoidcs. Prothorax a little longer than broad, strongly constricted behind, on the disc a shallow, longitudinal impression, basal margin distinctly elevated. Scutellum very small. Elytra parallel, sides a little narrowed before the middle; there also the upper surface is a little depressed. P u n t u a t i o $\mathrm{n}$ on head rather fine and dense, backwards sparser; on the prothorax fine and dense; on the elytra at the sides distinct and in rows, which run down to near the apex; these rows become shorter towards the middle; on the disc the punctuation is sparser, fine and irregular, on the apical half sparser and finer still. Colo u $\mathrm{r}$ a brownish red, with on each elytron, in the depression, at about basal third, a not sharply defined, separately forwardly curved, transverse, dark fascia; apical half of the elytra dark violet; here the suture remains red. Pubes cence erect, with a few dispersed, longer hairs. $\mathrm{Ha}$ a $\mathrm{rtufts}$ on the elytra: In the middle of the first fourth part an erect tuft of long, black hairs; in the depressed portion and near the apex on each elytron respectively two and one tufts of silvery-white hairs, which are all directed backwards. A n t e n n a e yellowish, in the middle darker, apices again yellow. Le gs less robust than in C. cyrtinoides, tibiae slender and slightly curved. Colour of the legs yellow, tibiae brown. Underside reddish yellow; first sternite as long as the three following ones together.

Only one specimen in the British Museum, labelled: Nilgiri Hills, H. L. Andrewes. 


\section{EXPLANATION OF THE FIGURES}

\section{PLATE IX}

Fig. 1. Thaneroclerus Buquet Lef.

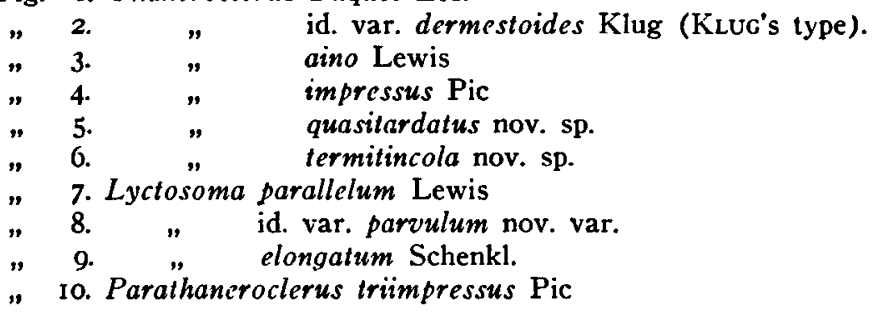

\section{PLATE X}

Fig. II. Allothaneroclerus tuberculatıs Schenkl.

" 12. Isoclerus pictus Lewis, type

" I3. " id., specimen from Chuzenji.

"14. " id., "cotype".

" $15 . \quad$ sarawacensis nov. sp.

" 16. Neoclerus nanus Schenkl.

"17. " id.

"18. " nilgiriensis nov. sp.

" 19. " ornatulus Lewis

" $20 . \quad$ quinquemaculatus Gorh.

"21. " notatus Pic.

" 22. Zenodosus sanguineus Say

"23. Ababa tantilla Lec.

"24. Cyrtinoclerus indicus nov. sp.

" 25. $"$ id.

\section{PLATE XI}

Fig. 26. Cyrtinoclerus cyrtinoides Chapin

N.B. The enlargement of the figures $I-25$ is $I: 8$. 
BIJDRAGEN TOT DE DIERKUNDE, AFL. 27

PLATE IX
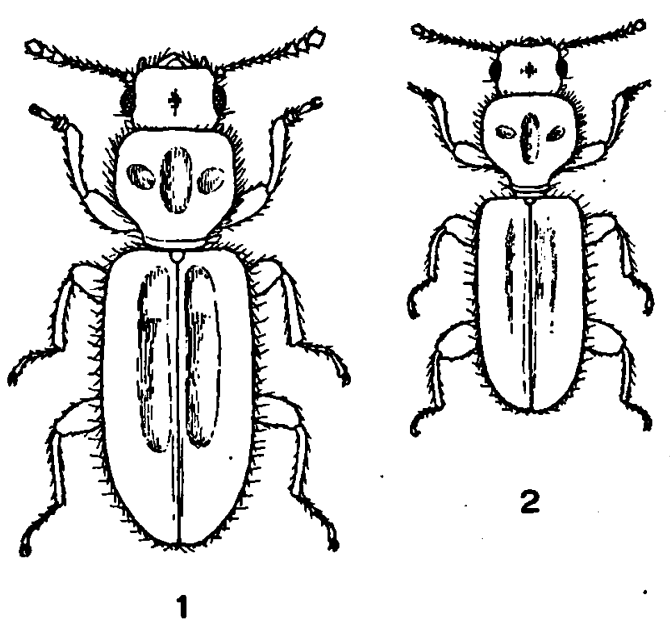

2
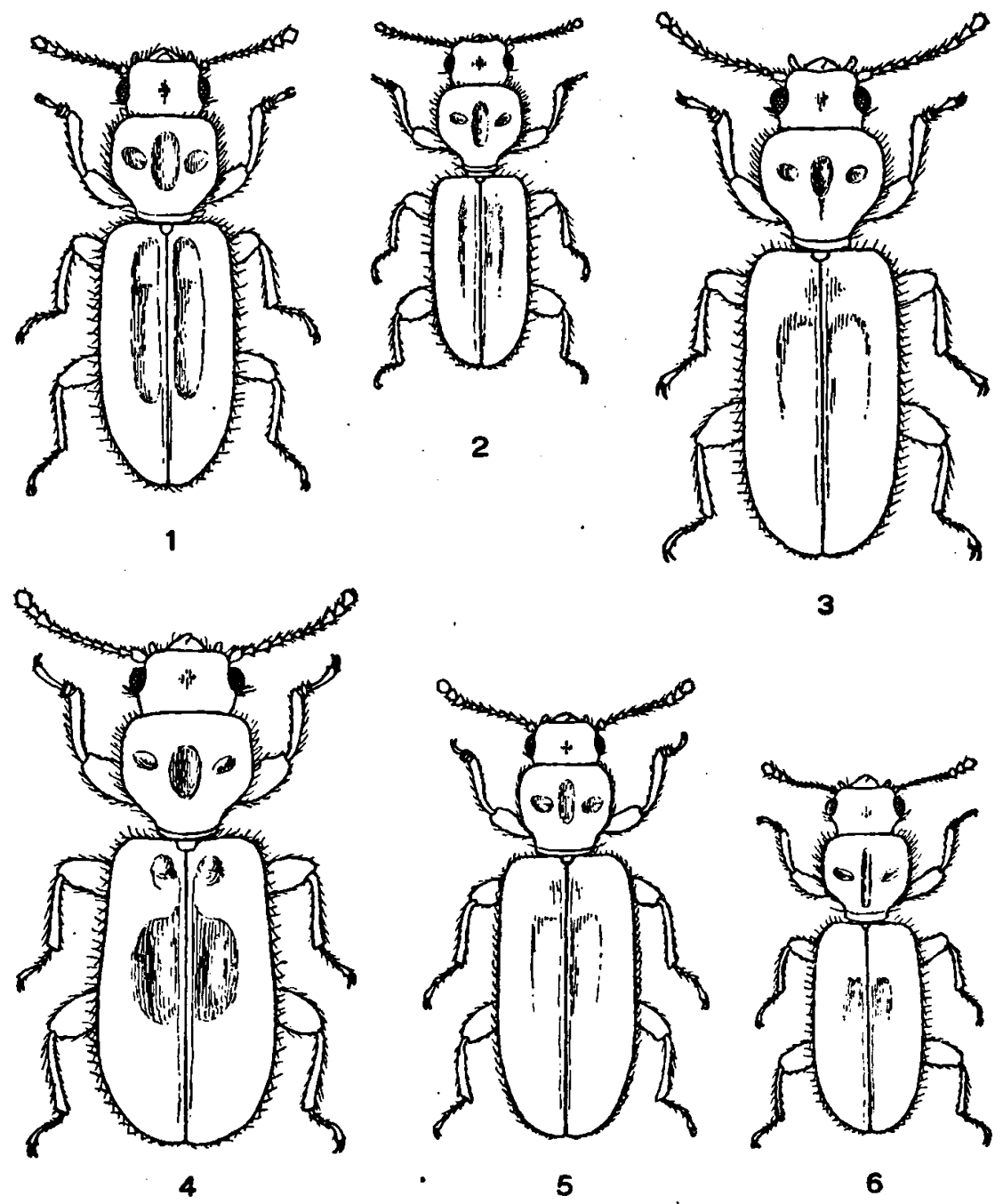

3
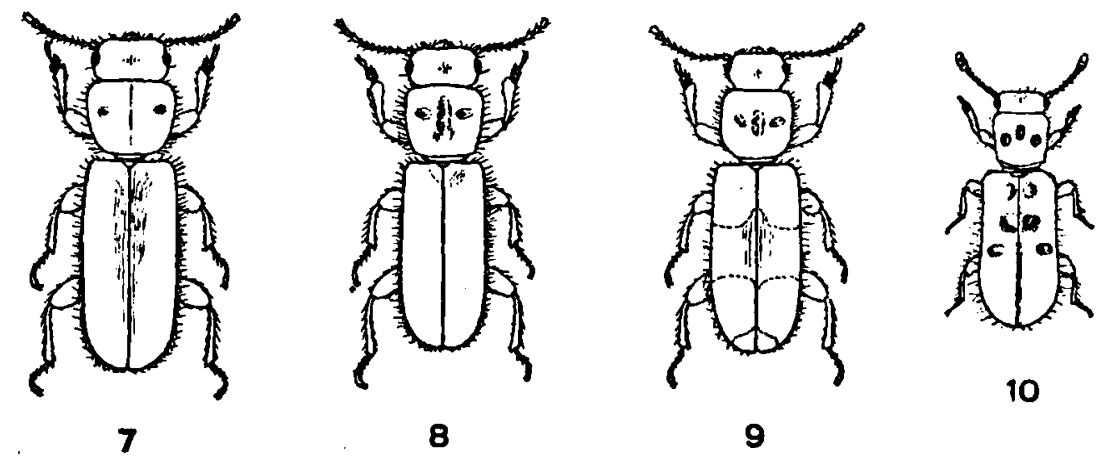

P. ven der Wial del. 
BIJDRAGEN TOT DE DIERKUNDE, AFL. 27

PLATE X
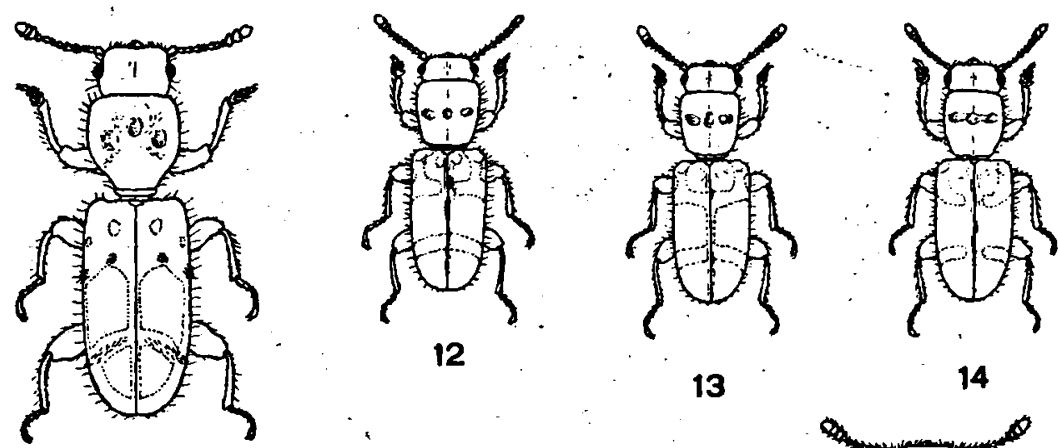

12

13

14

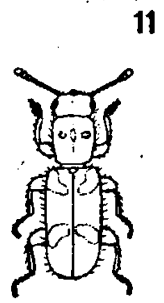

15

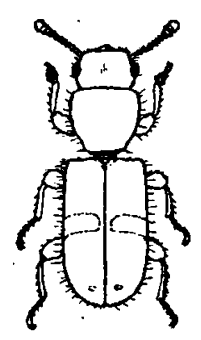

16

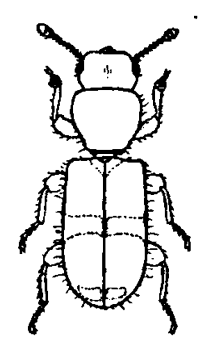

17

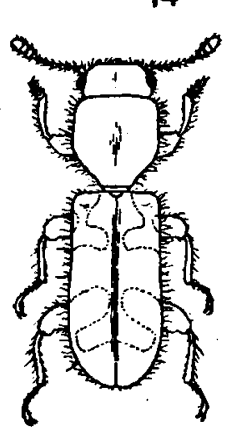

18

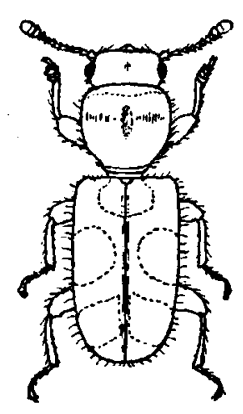

19
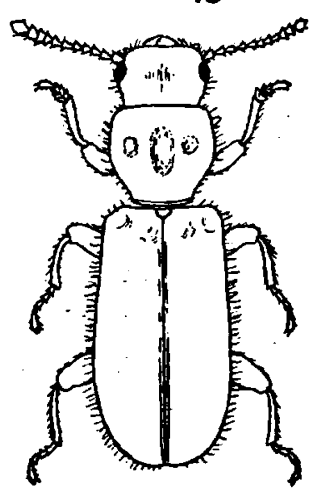

22

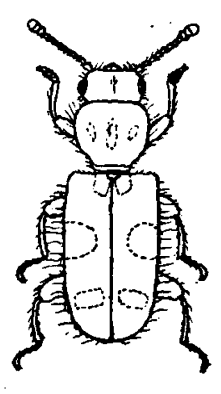

20

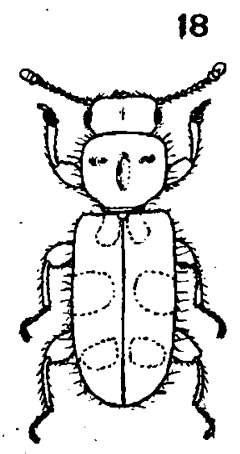

21 、

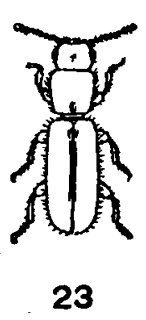

24

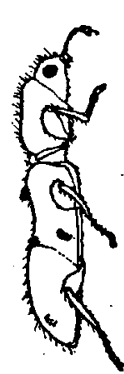

25

P. van der Wiel del. 


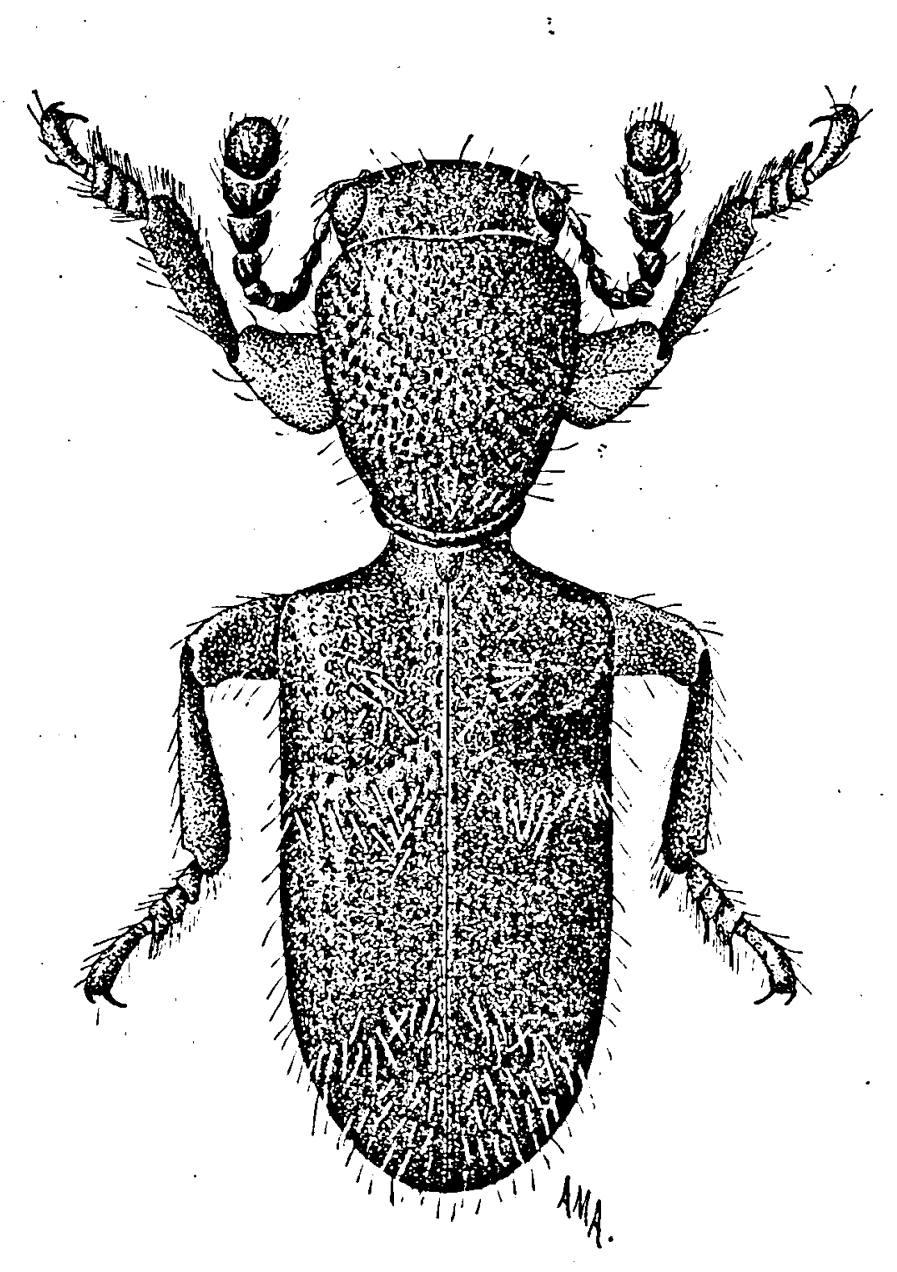

26 